\title{
Tiếp cận dựa trên quyền con người trong chính sách giảm nghèo của Việt Nam
}

\author{
Tạ Thị Bích Ngọc* \\ Truờng Đại hoc Khoa hoc Xã hội và Nhân văn, ĐHQGHN, \\ 336 Nguyến Trãi, Thanh Xuân, Hà Nội, Việt Nam \\ Nhận ngày 18 tháng 8 năm 2017 \\ Chỉnh sửa ngày 26 tháng 9 năm 2017; Chấp nhận đăng ngày 10 tháng 10 năm 2017
}

\begin{abstract}
Tóm tắt: Xóa bỏ tình trạng nghèo cùng cực và thiếu đói là một trong tám mục tiêu thiên niên kỷ (MDGs) được 189 quốc gia thành viên Liên hợp quốc nhất trí phấn đấu đạt được vào năm 2015 . Tại Việt Nam, giảm nghèo là chiến lược nhằm giải quyết đói nghèo và phát triển kinh tế quốc gia được thực hiện xuyên suốt trong nhiều thập kỷ thông qua nhiều chính sách cụ thể và bằng nhiều góc độ tiếp cận. Sử dụng tiếp cận dựa trên quyền con người, bài viết đánh giá những nội dung chủ yếu trong chính sách giảm nghèo ở Việt Nam trong giai đoạn hiện nay và đề xuất các định hướng xây dựng chính sách trong thời gian tới.
\end{abstract}

Tù khóa: Xóa đói giảm nghèo, Giảm nghèo, Chính sách xóa đói giảm nghèo, Chính sách giảm nghèo, Chính sách giảm nghèo bền vững, Tiếp cận dựa trên quyền con người, Quyền con người.

\section{Vài nét về cách tiếp cận dựa trên quyền con người}

Tiếp cận dựa trên quyền con người (Human Rights-based Approach - HRBA) là phương pháp tiếp cận "lấy các tiêu chuẩn về quyền con người làm cơ sở để xác định kết quả mong đợi và lấy các nguyên tắc về quyền con người làm điều kiện, khuôn khổ cho quá trình đạt được kết quả đó”. Cách tiếp cận này không chỉ quan tâm tới việc đạt được mục tiêu, mà đồng thời quan tâm, với tầm quan trọng tương tự, tới toàn bộ quá trình thực hiện mục tiêu. Nói cách khác, phương pháp HRBA "dành sụ quan tâm nhu nhau giữa một bên là nội dung hoạt động và

\footnotetext{
*ĐT.: 84-989767672.

Email: tabngoc@gmail.com

https://doi.org/10.25073/2588-1116/vnupam.4118
}

bên kia là cách thức thực hiện các hoạt động đó" $[1 ; 1]$. Điều này có nghĩa, sử dụng HRBA trong hoạch định chính sách sẽ đồng nghĩa với việc phải tiến hành song song 02 nhóm nhiệm vụ gồm: 1/ Xác định mục tiêu chính sách trong đó thể hiện rõ rằng kết quả của việc thực hiện chính sách chính là điều kiện, là cơ sở hoặc là tiền đề để người hưởng thụ tiến tới thực hiện được các quyền con người của họ; $2 /$ Xây dựng hệ thống giải pháp trong đó người thụ hưởng chính sách có vai trò chủ động và tích cực trong quá trình thực hiện chính sách, không phải chỉ thụ động chờ hưởng lợi từ các chính sách.

Để làm rõ các đặc trưng của HRBA, Britha Mikkelsen (2005) đã so sánh cách tiếp cận này với cách tiếp cận dựa trên nhu cầu (Need-based Appoach - NBA) theo bảng sau: 
Bảng 1 . So sánh cách tiếp cận dựa trên quyền con người và cách tiếp cận dựa trên nhu cầu [2; 17-18]

\begin{tabular}{|c|c|}
\hline NBA & HRBA \\
\hline Làm việc hướng tới nhũng kết quả của mục đích & Làm việc hướng tới những kết quả và quá trình của mục đích \\
\hline Nhìn nhận nhu cầu như là những đòi hỏi họ̣p lý & $\begin{array}{l}\text { Nhìn nhận rằng các quyền luôn luôn bao hàm các nghĩa vụ của } \\
\text { nhà nước }\end{array}$ \\
\hline $\begin{array}{l}\text { Sự trao quyền là không cần thiết để đáp ứng tất cả } \\
\text { các nhu cầu }\end{array}$ & $\begin{array}{l}\text { Nhìn nhận rằng các quyền chỉ có thể được thực thi với sự trao } \\
\text { quyên }\end{array}$ \\
\hline $\begin{array}{l}\text { Chấp nhận từ thiện như một động lực dẫn dắt tới } \\
\text { việc đáp ứng các nhu câu }\end{array}$ & $\begin{array}{l}\text { Cho rằng từ thiện là một động lực khiếm khuyết cho việc đáp } \\
\text { ứng các nhu câu }\end{array}$ \\
\hline $\begin{array}{l}\text { Tập trung vào những biểu hiện và nguyên nhân } \\
\text { trực tiếp của vấn đề }\end{array}$ & Tập trung vào những nguyên nhân kết cấu của vấn đề \\
\hline $\begin{array}{l}\text { Tập trung vào bối cảnh xã hội với một chút nhấn } \\
\text { mạnh vào chính sách }\end{array}$ & $\begin{array}{l}\text { Tập trung vào bối cảnh xã hội, kinh tế, văn hóa, cá nhân và } \\
\text { chính trị và định hướng chính sách }\end{array}$ \\
\hline \multicolumn{2}{|c|}{$\begin{array}{l}\text { Bảng 2. So sánh về lý giải khi nhìn nhận kết quả của cách tiếp cận dựa trên quyền con người và cách tiếp cận } \\
\text { dựa trên nhu cầu }[2 ; 25]\end{array}$} \\
\hline NBA & HRBA \\
\hline Nhu cầu được đáp ứng hay được hài lòng & Các quyền được tôn trọng, bảo vệ, tạo điều kiện \\
\hline $\begin{array}{l}\text { Nhu cầu không bao hàm các nghĩa vụ và trách } \\
\text { nhiệm, mặc dù chúng có thể đặt ra những hứa hẹn }\end{array}$ & $\begin{array}{l}\text { Quyền luôn bao hàm các nghĩa vụ và trách nhiệm liên } \\
\text { quan }\end{array}$ \\
\hline Nhu cầu không nhất thiết có tính phổ biến & Các quyền con người luôn luôn là phổ biến \\
\hline $\begin{array}{l}\text { Các nhu cầu cơ bản có thể đặt được bằng các chiến } \\
\text { lược mục tiêu }\end{array}$ & $\begin{array}{l}\text { Quyền con người chỉ có thể đạt được chỉ bởi sự quan tâm } \\
\text { tới cả mục đích lẫn quá trình }\end{array}$ \\
\hline $\begin{array}{l}\text { Nhu cầu có thể được xếp hạng bởi một hệ thống } \\
\text { cấp bậc ưu tiên }\end{array}$ & $\begin{array}{l}\text { Quyền con người là không thể phân chia bởi chúng độc } \\
\text { lập với nhau }\end{array}$ \\
\hline Nhu cầu có thể đạt được bởi lòng từ thiện & Lòng từ thiện không phản ánh nghĩa vụ hay trách nhiệm \\
\hline $\begin{array}{l}\text { Có thể hài lòng mà tuyên bố rằng "80\% trẻ em đã } \\
\text { đạt được nhu cầu tiêm chủng" }\end{array}$ & $\begin{array}{l}\text { Đối với HRBA, điều này có nghĩa là } 20 \% \text { trẻ em không } \\
\text { hưởng quyền được tiêm chủng }\end{array}$ \\
\hline $\begin{array}{l}\text { Chính phủ hiện chưa cần có những chính sách để } \\
\text { thực thi pháp luật về việc I-ốt hóa toàn bộ muối ăn }\end{array}$ & $\begin{array}{l}\text { Chính phủ đã chọn việc từ chối nghĩa vư của mình bằng } \\
\text { việc thất bại trong thực thi pháp luật về I-ốt hóa toàn bộ } \\
\text { muối ăn }\end{array}$ \\
\hline
\end{tabular}

Từ các so sánh trên, có 05 đặc điểm quan trọng nhất của HRBA trong đối sánh với NBA. Thư nhất, HRBA lấy quyền con người làm trung tâm cho việc phân tích và giải quyết mọi vấn đề xã hội. Thư hai, HRBA không coi trọng kêu gọi lòng từ thiện xã hội mà yêu cầu nhà nước thực thi đúng nghĩa vụ để đảm bảo quyền con người. Thư $b a, \mathrm{HRBA}$ khẳng định khi chủ thể của quyền (Rights-Holders) không được đáp ứng quyền của mình, thì chủ thể có nghĩa vụ (DutyBearers) có trách nhiệm phải cung cấp mọi phương tiện để chủ thể của quyền có thể đạt được các quyền của mình. Thú tur, HRBA đồng thời quan tâm như nhau tới cả mục tiêu và phương pháp đạt tới mục tiêu. Thư năm, HRBA không bị cản trở bởi các nội dung quy định sẵn có của hệ thống, mà hướng tới việc tác động làm thay đồi chính sách và pháp luật theo hướng đảm bảo các quyền cơ bản của con người. [2; 18-23]

Với những đặc điểm căn bản này, ưu điểm nổi trội của HRBA là kết quả thu được sẽ theo hướng phát triển con người tốt hơn và bền vững hơn. Điều này có được là do: $1 /$ Chính bản thân con người chủ động tham gia vào quá trình giải quyết vấn đề chứ không thụ động chờ đợi; 2/Đáp ứng các quyền cơ bản của con người đồng nghĩa với việc tạo ra nền tảng căn bản để con người tự phát triển trên mọi phương diện; 
3/Vai trò và trách nhiệm của nhà nước được nhấn mạnh trong việc thúc đẩy con người đạt được các quyền cơ bản của mình.

Tuy nhiên, HRBA là một cách tiếp cận mới. Lịch sử gắn HRBA với hoạt động của Liên hợp quốc, với dấu mốc năm 1993 khi Hội nghị Viên đã đặt ra yêu cầu tích hợp quyền con người vào trong các chương trình phát triển của tổ chức này. Tại Việt Nam, HRBA mới được nói đến nhiều kể từ đầu thập niên thứ hai của thế kỷ XXI và cũng gắn với Liên hợp quốc khi đây là thời điểm các tổ chức của Liên hợp quốc tại Việt Nam thực hiện nhiều hoạt động nhằm làm rõ vai trò của cách tiếp cận này đối với việc xây dựng khung pháp lý tại Việt Nam [3] và vai trò quan trọng của Quốc hội đối với sự phát triển của quyền con người [4]. Kể từ đó, cách tiếp cận này bước đầu được sử dụng để nghiên cứu và đánh giá nhiều lĩnh vực như bình đẳng giới, hôn nhân và gia đình, $\mathrm{y}$ tế, dạy nghề, biến đổi khí hậu, báo chí và truyền thông, quyền của các dân tộc thiểu số, quyền của người khuyết tật, quyền trẻ em, quyền của người đồng tính, song tính và chuyển giới (LGBT)....

Để thực hiện HRBA, cần đảm bảo 04 nội dung cơ bản. Thú nhất, sử dụng các chuẩn mực và nguyên tắc cơ bản về quyền con người trong quá trình xây dựng, thực thi và đánh giá kết quả. Thư hai, phân tích, đánh giá năng lực của các chủ thể liên quan, nâng cao năng lực của chủ thể quyền và tính chịu trách nhiệm của chủ thể có nghĩa vụ thực hiện quyền. Thứ $b a$, làm rõ mối quan hệ giữa chủ thể của quyền và chủ thể có nghĩa vụ thực hiện quyền. Thứ tur, quan tâm đến các nhóm dễ bị tổn thương, đặc biệt là nhóm dễ bị loại ra khỏi quá trình phát triển khi muốn đạt kết quả cho dự án. [2;31-33]

Như vậy, để đánh giá nội dung chính sách giảm nghèo theo HRBA, cần xem xét 04 phương diện: $1 /$ Sử dụng quyền con người làm căn cứ xây dựng chính sách; 2/ Làm rõ vai trò của nhà nước trong việc cung cấp điều kiện thực hiện quyền con người của người nghèo; $3 /$ Nâng cao năng lực của người nghèo (chủ thể quyền) và tính chủ động của các cơ quan nhà nước (chủ thể có nghĩa vụ thực hiện quyền); 4/Quan tâm đồng đều tới mục tiêu chính sách và phương pháp thực hiện chính sách.

\section{Chính sách giảm nghèo ở Việt Nam hiện nay}

\subsection{Quan niệm về nghèo ở Việt Nam}

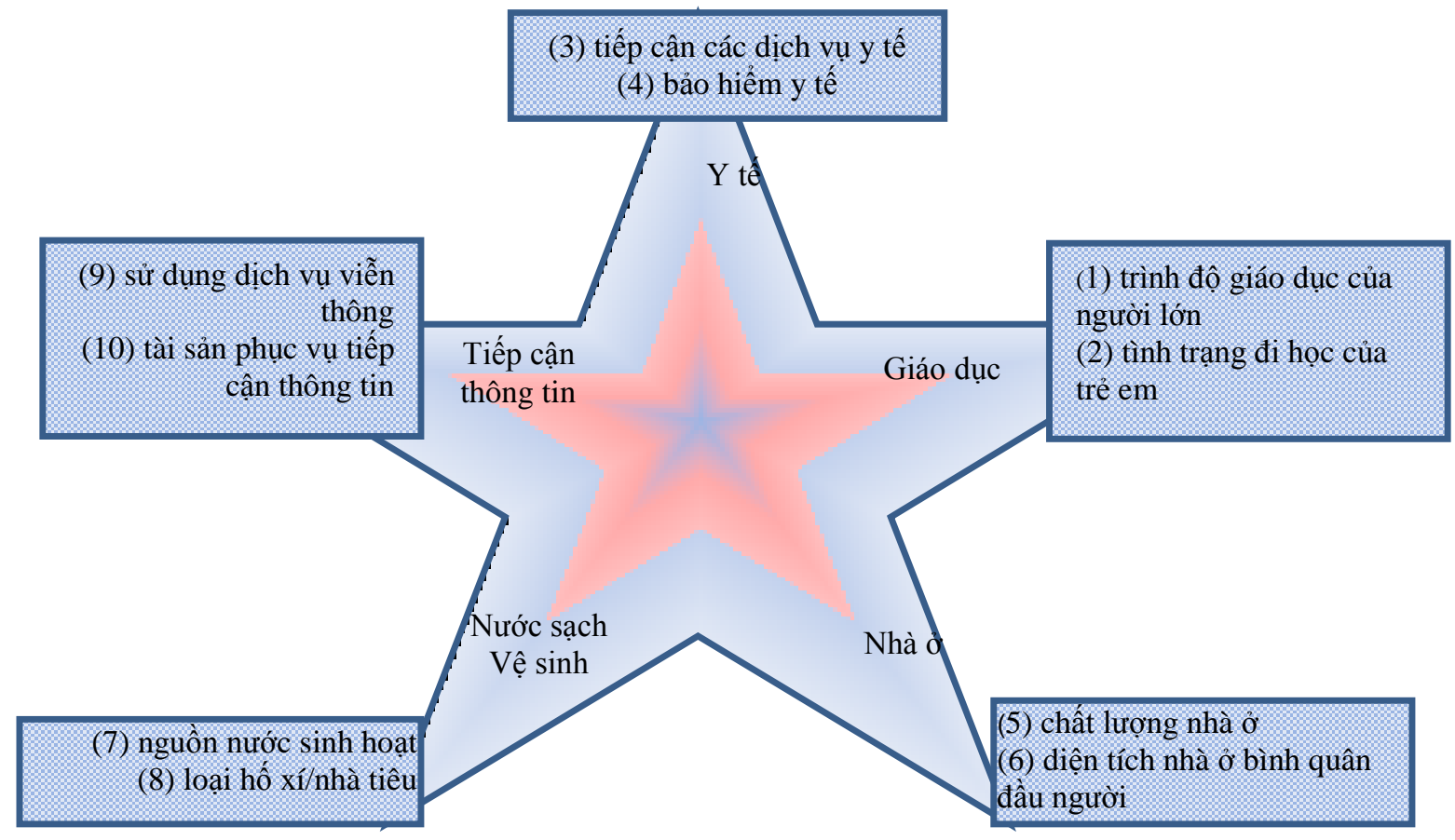


Trước đây, nghèo được cho là đồng nghĩa với thu nhập thấp. Tuy nhiên, cùng với quá trình phát triển của nhận thức và thực tiễn, các quan niệm về nghèo đã có nhiều thay đổi.

Tại Việt Nam, sau một thời gian dài thuần túy đo lường nghèo thông qua mức thu nhập bình quân, kể từ năm 2016, việc đo lường nghèo đã được chuyển đổi sang phương pháp tiếp cận đo lường nghèo đa chiều theo Quyết định 1614/QĐ-TTg ngày 15.9.2015 và được hướng dẫn bởi Quyết định 59/2015/QĐ-TTg ngày 19.11.2015 về việc ban hành chuẩn nghèo tiếp cận đa chiều áp dụng cho giai đoạn 2016 2020. Trong quá trình chuyển đổi, chuẩn nghèo về thu nhập và mức độ thiếu hụt tiếp cận các dịch vụ xã hội cơ bản được sử dụng song song, trong đó chuẩn thu nhập được coi là tiêu chí bổ sung để phân loại đối tượng nghèo đa chiều thành các nhóm khác nhau.

Căn cứ điều kiện và khả năng thực tế của địa phương, các tỉnh, thành phố trực thuộc Trung ương ban hành chuẩn nghèo với các tiêu chí về thu nhập và mức độ thiếu hụt của các chiều nghèo của riêng mình. Dưới đây là Bảng chỉ số chiều và mức độ thiếu hụt được ban hành kèm theo Quyết định 65/2015/QĐ-UBND ngày 23/12/2015 của UBND tỉnh Bình Dương về chuẩn nghèo tiếp cận đa chiều tỉnh Bình Dương giai đoạn 2016 - 2020 và chính sách bảo lưu đối với các hộ mới thoát nghèo:

Bảng 3. Bảng chỉ số chiều và mức độ thiếu hụt

\begin{tabular}{|c|c|c|c|c|}
\hline $\begin{array}{l}\text { Chiều } \\
\text { nghèo }\end{array}$ & $\begin{array}{l}\text { Tiêu chí để đo } \\
\text { lường }\end{array}$ & Ngưỡng thiếu hụt & $\begin{array}{l}\text { Cơ sở hình thành chiều nghèo } \\
\text { và tiêu chí đo lường }\end{array}$ & $\begin{array}{l}\text { Điểm } \\
\text { số }\end{array}$ \\
\hline \multirow[t]{2}{*}{$\begin{array}{l}\text { 1. Giáo } \\
\text { dục }\end{array}$} & $\begin{array}{l}1.1 \text { Trình độ giáo } \\
\text { dục của người } \\
\text { lớn }\end{array}$ & $\begin{array}{l}\text { Hộ gia đình có ít nhất } 1 \text { thành viên từ } \\
\text { đú } 15 \text { tuổi đến dưới } 30 \text { tuổi (sinh tứ } \\
\text { năm } 1986 \text { đến năm 2000) không tốt } \\
\text { nghiệp Trung học cơ sở và hiện } \\
\text { không đi học. }\end{array}$ & $\begin{array}{l}\text { Hiến pháp năm 2013; NQ 15/NQ- } \\
\text { TW Một số vấn đề chính sách xã } \\
\text { hội giai đoạn 2012-2020; Nghị } \\
\text { quyết số 41/2000/QH (bồ sung } \\
\text { bởi Nghị định số 88/2001/NĐ- } \\
\text { CP) }\end{array}$ & 10 \\
\hline & $\begin{array}{l}1.2 \text { Tình trạng đi } \\
\text { học của trẻ em }\end{array}$ & $\begin{array}{l}\text { Hộ gia đình có ít nhất } 1 \text { trẻ em trong } \\
\text { độ tuổi đi học (từ } 5 \text {-dưới } 15 \text { tuổi) hiện } \\
\text { không đi học. }\end{array}$ & $\begin{array}{l}\text { Hiến pháp năm 2013; Luật Giáo } \\
\text { dục 2005; Luật BV, chăm sóc và } \\
\text { giáo dục trẻe em; NQ 15/NQ- } \\
\text { TW Một số vấn đề chính sách xã } \\
\text { hội giai đoạn } 2012 \text { - } 2020 \text {. }\end{array}$ & 10 \\
\hline \multirow[t]{2}{*}{ 2. Y tế } & $\begin{array}{l}2.1 \text { Tiếp cận các } \\
\text { dịch vụ y tế }\end{array}$ & $\begin{array}{l}\text { Hộ gia đình có người bị ốm đau } \\
\text { nhưng không đi khám chữa bệnh(ốm } \\
\text { đau được xác định là bị bệnh/chấn } \\
\text { thương nặng đến mức phải nằm một } \\
\text { chô̂ và phải có người chăm sóc tại } \\
\text { giường hoặc nghỉ việc/học không } \\
\text { tham gia được các hoạt động bình } \\
\text { thường). }\end{array}$ & $\begin{array}{l}\text { Hiến pháp năm } 2013 . \\
\text { Luật Khám chữa bệnh. }\end{array}$ & 10 \\
\hline & $\begin{array}{l}2.2 \text { Bảo hiểm y } \\
\text { tế }\end{array}$ & $\begin{array}{l}\text { Hộ gia đình có ít nhất } 1 \text { thành viên từ } \\
6 \text { tuổi trở lên hiện tại không có bảo } \\
\text { hiểm y tế. }\end{array}$ & $\begin{array}{l}\text { Hiến pháp năm 2013; Luật bảo } \\
\text { hiểm y tế 2014; NQ 15/NQ- } \\
\text { TW Một số vấn đề chính sách xã } \\
\text { hội giai đoạn } 2012 \text { - } 2020 \text {. }\end{array}$ & 10 \\
\hline $\begin{array}{l}\text { 3. Nhà } \\
\text { ở }\end{array}$ & $\begin{array}{l}\text { 3.1. Chất lượng } \\
\text { nhà ở }\end{array}$ & $\begin{array}{l}\text { Hộ gia đình đang ở trong nhà thiếu } \\
\text { kiên cố hoặc nhà đơn sơ. } \\
\text { (Nhà ở chia thành } 4 \text { cấp độ: nhà kiên } \\
\text { cố, bán kiên cố, nhà thiếu kiên cố, } \\
\text { nhà đơn sơ). }\end{array}$ & $\begin{array}{l}\text { Luất Nhà ở; NQ 15/NQ-TW Một } \\
\text { số vấn đề chính sách xã hội giai } \\
\text { đoạn } 2012 \text { - 2020. }\end{array}$ & 10 \\
\hline
\end{tabular}




\begin{tabular}{|c|c|c|c|c|}
\hline & $\begin{array}{l}\text { 3.2 Diện tích nhà } \\
\text { ở bình quân đầu } \\
\text { người }\end{array}$ & $\begin{array}{l}\text { Diện tích nhà ở bình quân đầu người } \\
\text { của hộ gia đình nhỏ hơn } 8 \mathrm{~m} 2 \text {. }\end{array}$ & $\begin{array}{l}\text { Luật Nhà ở; Quyết } \\
\text { định 2127/QĐ-TTg của Thủ } \\
\text { tướng Chính phủ phê duyệt Chiến } \\
\text { lược phát triển nhà ở quốc gia đến } \\
\text { năm } 2020 \text { và tầm nhìn đến năm } \\
2030 \text {. }\end{array}$ & 10 \\
\hline \multirow[t]{2}{*}{$\begin{array}{l}\text { 4. Điều } \\
\text { kiện } \\
\text { sống }\end{array}$} & $\begin{array}{l}\text { 4.1 Nguồn nước } \\
\text { sinh hoạt }\end{array}$ & $\begin{array}{l}\text { Hộ gia đình không được tiếp cận } \\
\text { nguồn nước hợp vệ sinh. }\end{array}$ & $\begin{array}{l}\text { NQ 15/NQ-TW Một số vấn đề } \\
\text { chính sách xã hội giai đoạn } 2012 \text { - } \\
2020 .\end{array}$ & 10 \\
\hline & $\begin{array}{l}\text { 4.2. Hố xí/nhà vệ } \\
\text { sinh }\end{array}$ & $\begin{array}{l}\text { Hộ gia đình không sử dụng hố xí/nhà } \\
\text { tiêu hợp vệ sinh. }\end{array}$ & $\begin{array}{l}\text { NQ 15/NQ-TW Một số vấn đề } \\
\text { chính sách xã hội giai đoạn } 2012 \text { - } \\
2020 .\end{array}$ & 10 \\
\hline \multirow[t]{2}{*}{$\begin{array}{l}\text { 5. Tiếp } \\
\text { cận } \\
\text { thông } \\
\text { tin }\end{array}$} & $\begin{array}{l}5.1 \text { Sử dụng dịch } \\
\text { vụ viễn thông }\end{array}$ & $\begin{array}{l}\text { Hộ gia đình không có thành viên nào } \\
\text { sừ dụng thuê bao điện thoại và } \\
\text { internet. }\end{array}$ & $\begin{array}{l}\text { Luật Viễn thông., } \\
\text { NQ 15/NQ-TW Một số vấn đề } \\
\text { chính sách xã hội giai đoạn } 2012 \text { - } \\
2020 .\end{array}$ & 10 \\
\hline & $\begin{array}{l}5.2 \text { Tài sản phục } \\
\text { vụ tiếp cận thông } \\
\text { tin }\end{array}$ & $\begin{array}{l}\text { Hộ gia đình không có tài sản nào } \\
\text { trong số các tài sản: Ti vi, radio, máy } \\
\text { tính; và không nghe được hệ thống } \\
\text { loa đài truyền thanh xã. }\end{array}$ & $\begin{array}{l}\text { Luật Thông tin truyền thông; } \\
\text { NQ 15/NQ-TW Một số vấn đề } \\
\text { chính sách xã hội giai đoạn } 2012 \text { - } \\
2020 \text {. }\end{array}$ & 10 \\
\hline
\end{tabular}

\subsection{Nội dung co bản của chính sách giảm nghèo ở Việt Nam}

Trong giai đoạn hiện nay, cùng với Nghị quyết số $30 \mathrm{a} / 2008 / \mathrm{NQ}-\mathrm{CP}$ của Chính phủ ngày 27/12/2008 về Chương trình hỗ trợ giảm nghèo nhanh và bền vững đối với 61 huyện và các văn bản hướng dẫn thực hiện đi kèm, nội dung chính sách giảm nghèo của Việt Nam còn được thể hiện qua nhiều văn bản quy phạm pháp luật, văn bản chỉ đạo điều hành và nghị quyết của chính phủ. Sử dụng cách phân nhóm của Chỉ thị số 01/CT-TTg của Thủ tướng Chính phủ ngày 06/1/2017 về việc tăng cường chỉ đạo thực hiện Chương trình mục tiêu quốc gia Giảm nghèo bền vững giai đoạn 2016-2020, có thể khái lược như sau:

Thứ nhất, nhóm chính sách hỗ trọ phát triển sản xuất, nâng cao thu nhập cho hộ nghèo

\section{Một là chính sách hỗ trọ tín dụng}

* Văn bản chính sách chủ yếu: Quyết định 28/2015/QĐ-TTg ngày 21/07/2015 về tín dụng đối với hộ mới thoát nghèo; Quyết định 750/QĐ-TTg ngày 01/06/2015 về điều chỉnh giảm lãi suất cho vay đối với chương trình tín dụng chính sách tại Ngân hàng Chính sách xã hội do Thủ tướng Chính phủ ban hành; Quyết định 15/2013/QĐ-TTg ngày 23/02/2013 về tín dụng đối với hộ cận nghèo

\section{* Nội dung co bản của chính sách:}

Cho vay với lãi suất ưu đãi đối với hộ nghèo, hộ mới thoát nghèo, và hộ cận nghèo thông qua Ngân hàng Chính sách xã hội. Một số địa phương (Lâm Đồng) còn mở rộng áp dụng đối với hộ có bình quân thu nhập thấp (hộ có thu nhập bình quân thấp hơn hoặc bằng $150 \%$ so với thu nhập của chuẩn hộ nghèo).

Ngoài các hỗ trợ do nhà nước thực hiện, các quy định hiện này còn khuyến khích các chủ thể ngoài nhà nước tham gia hỗ trợ tín dụng cho người nghèo như: Quỹ hỗ trợ vốn cho người lao động nghèo tự tạo việc làm (CEP), Quỹ hỗ trợ cựu chiến binh nghèo Thành phố Hồ Chí Minh, Quỹ hỗ trợ phụ nữ nghèo Thanh Hóa,..

\section{Hai là chính sách hỗ trọ lao động và việc làm}

* Văn bản chính sách chủ yếu: Quyết định 755/QĐ-TTg ngày 20/5/2013 phê duyệt chính sách hỗ trợ đất ở, đất sản xuất, nước sinh hoạt cho hộ đồng bào dân tộc thiểu số nghèo và hộ nghèo ở xã, thôn, bản đặc biệt khó khăn; 
Quyết định 29/2013/QĐ-TTg ngày 20/05/2013 về chính sách hỗ trợ giải quyết đất ở và việc làm cho đồng bào dân tộc thiểu số nghèo, đời sống khó khăn vùng đồng bằng sông Cửu Long giai đoạn 2013 - 2015; Quyết định 71/2009/QĐ-TTg ngày 29/4/2009 của Thủ tướng Chính phủ về phê duyệt đề án hỗ trợ các huyện nghèo đẩy mạnh xuất khẩu lao động góp phần giảm nghèo bền vững giai đoạn 2009 - 2020

* Nội dung co bản của chính sách:

a, Các chính sách trục tiếp

- Giao đất sản xuất cho hộ nghèo. Nơi không còn đất sản xuất thì hỗ trợ: Chuyển đổi nghề (chi phí học nghề và các ưu đãi liên quan đển dạy nghề; vốn để mua sắm nông cụ, máy móc làm dịch vụ sản xuất nông nghiệp, để làm nghề khác); Xuất khẩu lao động (Hỗ trợ người lao động nâng cao trình độ văn hóa để tham gia xuất khẩu lao động; Hỗ trợ người lao động học nghề, ngoại ngữ, bồi dưỡng kiến thức cần thiết theo quy định của Luật Người lao động Việt Nam đi làm việc ở nước ngoài theo hợp đồng; hỗ trợ chi phí khám sức khỏe; làm hộ chiếu, viza và lý lịch tư pháp để tham gia xuất khẩu lao động; Hỗ trợ rủi ro; tín dụng ưu đãi nếu có nhu cầu vay vốn để đi xuất khẩu lao động); Giao khoán bảo vệ rừng và trồng rừng.

- Cho hộ nghèo vay vốn để tạo việc làm, phát triển sản xuất.

- Trực tiếp cấp phát một lần toàn bộ tiền mua giống, phân bón cho việc chuyển đổi cây trồng, vật nuôi có giá trị kinh tế cao; ưu tiên hỗ trợ trồng lúa lai, ngô lai; mua giống, phân bón cho việc chuyển đổi cây trồng, vật nuôi có giá trị kinh tế cao; ưu tiên hỗ trợ trồng lúa lai, ngô lai. Đối với hộ nghèo ở thôn, bản vùng giáp biên giới trong thời gian chưa tự túc được lương thực thì được hỗ trợ gạo/khẩu/tháng.

\section{b, Các chính sách gián tiếp}

- Tăng cường dạy nghề gắn với tạo việc làm: đầu tư xây dựng mỗi huyện 01 cơ sở dạy nghề tổng hợp được hưởng các chính sách ưu đãi, có nhà ở nội trú cho học viên để tổ chức dạy nghề tại chỗ cho lao động nông thôn về sản xuất nông, lâm, ngư nghiệp, ngành nghề phi nông nghiệp; dạy nghề tập trung để đưa lao động nông thôn đi làm việc tại các doanh nghiệp và xuất khẩu lao động.

- Hỗ trợ cán bộ khuyến nông, khuyến lâm, khuyến ngư, dịch vụ bảo vệ thực vật, thú y, vệ sinh an toàn thực phẩm cho địa phương nghèo; Hỗ trợ địa phương tiền xúc tiến thương mại, quảng bá, giới thiệu sản phẩm, nhất là nông, lâm, thủy đặc sản của địa phương; thông tin thị trường cho nông dân.

- Khuyến khích đầu tư sản xuất, chế biến, kinh doanh trên địa bàn huyện nghèo; Khuyến khích các tổ chức, nhà khoa học trực tiếp nghiên cứu, ứng dụng, chuyển giao tiến bộ khoa học công nghệ, nhất là việc tuyển chọn, chuyển giao giống cây trồng, giống vật nuôi cho sản xuất.

Thứ hai, nhóm chính sách hỗ trọ’ tiếp cận các dịch vụ xã hội cơ bản

Một là chính sách hỗ trọ về y tế và chăm sóc sức khỏe

* Văn bản chính sách chủ yếu: Quyết định 705/QĐ-TTg ngày 08/05/2013 nâng mức hỗ trợ đóng bảo hiểm y tế cho đối tượng người thuộc hộ gia đình cận nghèo; Quyết định 14/2012/QĐ-TTg ngày $01 / 3 / 2012$ về việc sửa đổi, bổ sung một số chế độ hỗ trợ từ Quỹ Khám, chữa bệnh cho người nghèo; Thông tư liên tịch 07/2016/TTLT-BYT-BTC-BLĐTBXH hướng dẫn Nghị định 39/2015/NĐ-CP ngày 15/04/2016 quy định chính sách hỗ trợ cho phụ nữ thuộc hộ nghèo là người dân tộc thiểu số khi sinh con đúng chính sách dân số.

* Nội dung co bản của chính sách: Lập quỹ khám, chữa bệnh cho người nghèo; Cấp Bảo hiểm y tế cho người nghèo, hỗ trợ mức đóng Bảo hiểm y tế cho đối tượng cận nghèo. Một số địa phương mở rộng hỗ trợ bảo hiểm y tế cho hộ thoát nghèo (Bà Rịa - Vũng Tàu); Hố trợ cho phụ nữ thuộc hộ nghèo là người dân tộc thiểu số khi sinh con đúng chính sách dân số; Một số địa phương còn có hỗ trợ dinh dưỡng cho người nghèo (Lào Cai).

\section{Hai là chính sách hỗ trọ về giáo dục}

* Văn bản chính sách chủ yếu: Nghị định 86/2015/NĐ-CP ngày 02/10/2015 quy định về cơ chế thu, quản lý học phí đối với cơ sở giáo 
dục thuộc hệ thống giáo dục quốc dân và chính sách miễ̂n, giảm học phí, hỗ trợ chi phí học tập từ năm học 2015 - 2016 đến năm học 2020 2021; Quyết định 157/2007/QĐ-TTg ngày 27/9/2007 của Thủ tướng Chính phủ về tín dụng đối với học sinh, sinh viên.

* Nội dung co bản của chính sách:

a, Các chính sách trực tiếp

- Miễn học phí đối với: Trẻ em học mẫu giáo và học sinh phổ thông có cha mẹ thuộc diện hộ nghèo; Học sinh, sinh viên học tại các cơ sở giáo dục nghề nghiệp và giáo dục đại học là người dân tộc thiểu số thuộc hộ nghèo và hộ cận nghèo.

- Giảm 50\% học phí đối với trẻ em học mẫu giáo và học sinh phổ thông có cha mẹ thuộc hộ cận nghèo.

- Hỗ trợ chi phí học tập đối với trẻ em học mẫu giáo và học sinh phổ thông có cha mẹ thuộc diện hộ nghèo.

- Cho vay vốn để đi học đối với học sinh, sinh viên là thành viên của hộ nghèo theo học tại các trường đại học (hoặc tương đương đại học), cao đẳng, trung cấp chuyên nghiệp và tại các cơ sở đào tạo nghề.

\section{b, Các chính sách gián tiếp}

Bố trí đủ giáo viên cho các huyện nghèo; hỗ trợ nhà ở cho giáo viên thôn, bản; xây dựng trường Dân tộc nội trú cấp huyện theo hướng liên thông với các cấp học ở huyện; Mở rộng chính sách đào tạo ưu đãi theo hình thức cử tuyển và theo địa chỉ cho học sinh người dân tộc thiểu số.

\section{Ba là chính sách hỗ trọ' về nhà ở, đất ở}

* Văn bản chính sách chủ yếu: Quyết định 48/2014/QĐ-TTg ngày 28/08/2014 về chính sách hỗ trợ hộ nghèo xây dựng nhà ở phòng, tránh bão, lụt khu vực miền Trung; Quyết định 755/QĐ-TTg ngày 20/5/2013 của Thủ tướng Chính phủ phê duyệt chính sách hỗ trợ đất ở, đất sản xuất, nước sinh hoạt cho hộ đồng bào dân tộc thiểu số nghèo và hộ nghèo ở xã, thôn, bản đặc biệt khó khăn.
* Nộ dung co bản của chính sách: Giao đất ở cho hộ nghèo làm nhà ở; Cho hộ nghèo vay vốn cải tạo, xây dựng nhà ở.

\section{Bốn là chính sách hỗ trọ về̀ nước sạch và vệ sinh môi trường}

* Văn bản chính sách chủ yếu: Quyết định 755/QĐ-TTg ngày 20/5/2013 của Thủ tướng Chính phủ phê duyệt chính sách hỗ trợ đất ở, đất sản xuất, nước sinh hoạt cho hộ đồng bào dân tộc thiểu số nghèo và hộ nghèo ở xã, thôn, bản đặc biệt khó khăn.

* Nội dung cơ bản của chính sách:

Hỗ trợ tiền đối với hộ dân tộc thiểu số nghèo, hộ nghèo ở các xã, thôn, bản đặc biệt khó khăn có khó khăn về nước sinh hoạt để xây dựng bể chứa nước, đào giếng nước hoặc tự tạo nguồn nước sinh hoạt. Hỗ trợ đầu tư xây dựng, duy tu bảo dưỡng những công trình nước sinh hoạt tập trung.

Ngoài ra, một số nội dung được tích hợp trong các chương trình dự án tổng thể có sự tham gia của các chủ thể ngoài nhà nước như: Trao tặng bồn chứa nước sạch cho hộ nghèo tại các vùng bị ảnh hưởng của hạn hán và xâm nhập mặn trên cơ sở kêt hợp với các tổ chức ngoài nhà nước $[5,6]$; Xây dựng nhà vệ sinh cho hộ nghèo (dự án Tiểu hợp phần vệ sinh nông thôn, thuộc Dự án Quản lý thủy lợi phục vụ phát triển nông thôn vùng Đồng bằng sông Cửu Long (WB6)) [7]; Vay vốn để đầu tư cải tạo, nâng cấp, xây dựng mới các công trình nước sạch, công trình vệ sinh, bảo đảm theo tiêu chuẩn quốc gia về nước sạch và vệ sinh môi trường nông thôn (Quyết định 62/2004/QĐ-TTg về tín dụng thực hiện Chiến lược quốc gia về cấp nước sạch và vệ sinh môi trường nông thôn)...

\section{Năm là chính sách hỗ trọ' về thông tin}

* Văn bản chính sách chủ yếu: Thông tư 06/2017/TT-BTTTT ngày 02/6/2017 hướng dẫn thực hiện dự án truyền thông và giảm nghèo về thông tin thuộc Chương trình Mục tiêu quốc gia Giảm nghèo bền vững giai đoạn 2016 - 2020

* Nộ dung co bản của chính sách: Đào tạo, bồi dưỡng kỹ năng chuyên môn, nghiệp vụ cho 
cán bộ thông tin và truyền thông cơ sở; Tăng cường nội dung thông tin; Hỗ trợ phương tiện nghe - xem cho các hộ nghèo (Ti vi màu cỡ 32 inch và Radio); Trang bị phương tiện tác nghiệp phục vụ thông tin cổ động tại huyện, xã; Xây dựng các điểm tuyên truyền cổ động cố định; Xây dựng nội dung chương trình tuyên truyền cổ động; Thiết lập cụm thông tin cơ sở tại các khu vực cửa khẩu, biên giới, trung tâm giao thương; Lưu trữ, quảng bá các sản phẩm báo chí, các chương trình phát thanh, truyền hình và các sản phẩm thông tin khác phục vụ mục tiêu giảm nghèo về thông tin.

Thứ ba, nhóm chính sách hỗ trợ phát triển hạ tầng các vùng khó khăn, vùng có tỷ lệ hộ nghèo cao xã hội

Một là chính sách phát triển kinh tế -

Đẩy nhanh thực hiện quy hoạch các điểm dân cư ở những nơi có điều kiện và những nơi thường xảy ra thiên tai; nâng cao hiệu quả đầu tư. Uu tiên đầu tư cho các công trình hạ tầng kinh tế - xã hội. Đẩy mạnh công tác truyền thông, vận động kết hợp cung cấp các dịch vụ kế hoạch hóa gia đình để nâng cao chất lượng dân số của các huyện nghèo.

\section{Hai là chính sách nhân lục}

* Văn bản chính sách chủ yếu: Quyết định 170/QĐ-TTG ngày 26/01/2011 Phê duyệt Dự án thí điểm tuyển chọn 600 trí thức trẻ ưu tú, có trình độ đại học tăng cường về làm Phó Chủ tịch Ủy ban nhân dân xã thuộc 62 huyện nghèo; Quyết định 08/2011/QĐ-TTG ngày 26/01/2011 về tăng cường cán bộ cho các xã thuộc huyện nghèo để thực hiện Nghị quyết số 30a/2008/NQ-CP ngày 27 tháng 12 năm 2008 của Chính phủ về Chương trình hỗ trợ giảm nghèo nhanh và bền vững đối với 61 huyện nghèo

* Nội dung cơ bản của chính sách: Chế độ đãi ngộ thỏa đáng để thu hút khuyến khích trí thức trẻ về tham gia tổ công tác tại các xã thuộc huyện nghèo; Đào tạo cán bộ tại chỗ; Nâng cao năng lực cho đội ngũ cán bộ cơ sở; Luân chuyển và tăng cường cán bộ tỉnh, huyện về xã đảm nhận các cương vị lãnh đạo chủ chốt để tổ chức triển khai thực hiện cơ chế, chính sách đối với các huyện nghèo.

\section{Thứ tư, các chính sách khác}

\section{Một là chính sách trọ giúp pháp lý}

* Văn bản chính sách chủ yếu: Quyết định 32/2016/QĐ-TTg ngày 08/08/2016 Ban hành chính sách trợ giúp pháp lý cho người nghèo, đồng bào dân tộc thiểu số tại các huyện nghèo, xã nghèo, thôn, bản đặc biệt khó khăn giai đoạn 2016 - 2020 và hỗ trợ vụ việc tham gia tố tụng có tính chất phức tạp hoặc điển hình

* Nội dung co bản của chính sách: Hỗ trợ thực hiện vụ việc tham gia tố tụng có tính chất phức tạp hoặc điển hình; Cung cấp dịch vụ pháp lý miễn phí theo các hình thức: Tư vấn pháp luật; Tham gia tố tụng; Đại diện ngoài tố tụng; và các hình thức khác theo quy định của pháp luật về trợ giúp pháp lý; Tổ chức các đợt trợ giúp pháp lý lưu động; Thành lập, củng cố và tổ chức sinh hoạt Câu lạc bộ trợ giúp pháp lý...

\section{Hai là chính sách hỗ trọ tiền điện}

* Văn bản chính sách chủ yếu: Quyết định 28/2014/QĐ-TTg của Thủ tướng Chính phủ ngày 07/4/2014 Quy định về cơ cấu biểu giá bán lẻ điện

* Nội dung cơ bản của chính sách: Hỗ trợ tiền điện cho mục đích sinh hoạt cho hộ nghèo. Mức hỗ trợ hàng tháng tương đương tiền điện sử dụng $30 \mathrm{kWh}$ tính theo mức giá bán lẻ điện sinh hoạt bậc 1 hiện hành.

\section{3. Đánh giá nọi dung chính sách chính sách} giảm nghèo ở Việt Nam

Chính sách giảm nghèo hiện nay là sản phẩm có sự kế thừa liên tiếp của quá trình đấu tranh chống đói nghèo trong lịch sử nhà nước Việt Nam. Trên cơ sở điều kiện kinh tế - xã hội chung của đất nước và từ thực tiễn các biến động liên quan tới đói nghèo, nội dung chính sách xóa đói giảm nghèo (trước đây) và chính sách giảm nghèo bền vững (hiện nay) luôn có sự điều chỉnh. Sử dụng HRBA, có thể đánh giá nội dung chính sách giảm nghèo ở Việt Nam như sau: 
2.3.1. Về việc sủ dụng quyền con nguời làm căn cứ xây dựng chính sách

Thư nhất, các hợp phần của chính sách giảm nghèo tuoong thich trực tiếp với một phần hoạc toàn bộ đối với một quyền hay một nhóm quyền con ngườ đã được nêu trong Hiến pháp 2013

Tại Việt Nam, Hiến pháp 2013 là văn bản tối cao thừa nhận, tôn trọng và bảo vệ quyền con người một cách mạnh mẽ, rõ ràng và hiện đại nhất. Hiến pháp dành toàn bộ Chương II với 36 điều (từ Điều 14 đến Điều 49) để quy định về quyền con người, quyền và nghĩa vụ cơ bản của công dân. So với Hiến pháp năm 1992, Hiến pháp năm 2013 đã bổ sung 05 quyền hoàn toàn mới và sửa đổi, bổ sung trên 30 quyền còn lại. Các quyền con người được đề cập đến đều là những quyền thiết yếu, phủ khắp các quyền về chính trị, dân sự, kinh tế, văn hóa, xã hội và phù hợp với các Công ước quốc tế về quyền con người mà Việt Nam là thành viên.

Về cơ bản, các hợp phần của chính sách giảm nghèo tương thích trực tiếp với một phần hoặc toàn bộ đối với một quyền hay một nhóm quyền con người đã được nêu trong Hiến pháp 2013. Toàn bộ chính sách và việc thực thi chính sách gián tiếp tương thích với quyền đảm bảo an sinh xã hội.

Bảng 4. Tương quan giữa các hợp phần của Chính sách giảm nghèo và các quyền liên quan được đề cập trong Hiến pháp 2013

\begin{tabular}{|c|c|c|c|}
\hline \multirow{2}{*}{$\begin{array}{l}\text { Các hợp phần của } \\
\text { Chính sách giảm nghèo }\end{array}$} & & \multicolumn{2}{|l|}{ Các quyền liên quan } \\
\hline & & Trực tiếp & Gián tiếp \\
\hline \multirow[t]{2}{*}{$\begin{array}{l}\text { Nhóm chính sách hỗ trợ } \\
\text { phát triển sản xuất, nâng } \\
\text { cao thu nhập cho hộ nghèo }\end{array}$} & $\begin{array}{l}\text { Chính sách hỗ trợ tín dụng } \\
\text { Chính sách hỗ trợ lao động và } \\
\text { việc làm }\end{array}$ & $\begin{array}{l}\text { Quyền làm việc, lựa chọn nghề } \\
\text { nghiệp, việc làm và nơi làm } \\
\text { việc (Khoản } 1 \text { Điều } 35)\end{array}$ & \multirow[t]{10}{*}{$\begin{array}{l}\text { Quyền được } \\
\text { đảm bảo an } \\
\text { sinh xã hội } \\
\text { (Điều 34) }\end{array}$} \\
\hline & $\begin{array}{l}\text { Chính sách hỗ trợ về y tế và } \\
\text { chăm sóc sức khỏe }\end{array}$ & $\begin{array}{l}\text { Quyền được bảo vệ, chăm } \\
\text { sóc sức khỏe, bình đẳng trong } \\
\text { việc sử dụng các dịch vụ y tế } \\
\text { (Khoản } 1 \text { Điều } 38 \text { ) }\end{array}$ & \\
\hline \multirow{4}{*}{$\begin{array}{l}\text { Nhóm chính sách hỗ trợ } \\
\text { tiếp cận các dịch vụ xã hội } \\
\text { cơ bản }\end{array}$} & Chính sách hỗ trợ về giáo dục & $\begin{array}{l}\text { Quyền được giáo dục của trẻ } \\
\text { em (Khoản } 1 \text { Điều } 37 \text { ) và quyền } \\
\text { được học tập của thanh niên } \\
\text { (Khoản } 2 \text { Điều } 37 \text { ) }\end{array}$ & \\
\hline & $\begin{array}{l}\text { Chính sách hỗ trợ về nhà ở, } \\
\text { đất ở }\end{array}$ & $\begin{array}{l}\text { Quyền có nơi ở hợp pháp } \\
\text { (Khoản } 1 \text { Điều 22) }\end{array}$ & \\
\hline & $\begin{array}{l}\text { Chính sách hỗ trợ về nước } \\
\text { sạch và vệ sinh môi trường }\end{array}$ & $\begin{array}{l}\text { Quyền sống trong môi trường } \\
\text { trong lành (Điều 43) }\end{array}$ & \\
\hline & Chính sách hỗ trợ về thông tin & $\begin{array}{l}\text { Quyền tiếp cận thông tin (Điều } \\
\text { 25) }\end{array}$ & \\
\hline \multirow{3}{*}{$\begin{array}{l}\text { Nhóm chính sách hỗ trợ } \\
\text { phát triển hạ tầng các vùng } \\
\text { khó khăn, vùng có tỷ lệ hộ } \\
\text { nghèo cao }\end{array}$} & $\begin{array}{l}\text { Chính sách phát triển kinh tế - } \\
\text { xã hội }\end{array}$ & & \\
\hline & Chính sách nhân lực & & \\
\hline & Chính sách trợ giúp pháp lý & & \\
\hline Các chính sách khác & Chính sách hỗ trợ tiền điện & & \\
\hline
\end{tabular}

Đây là một điểm tích cực và rất có ý nghĩa bởi rất nhiều nội dung của các hợp phần này được xây dựng hoặc kế thừa từ khá lâu trước khi Hiến pháp 2013 được ban hành và có hiệu 
lực. Nó cho thấy bản chất đúng đắn của chính sách, đồng thời là biểu hiện quan trọng của việc lấy các nội dung căn bản của quyền con người làm căn cứ để xây dựng nội dung chính sách.

Tuy nhiên, có thể nhận thấy, nội dung một số hợp phần chưa khỏa lấp được hết các thiếu hụt trong khả năng thực thi một số quyền của người nghèo. Cụ thể:

- Ủu đãi về giáo dục mới tập trung vào việc thực hiện quyền được giáo dục của trẻ em nghèo, cần mở rộng thêm đối với các quyền khác của trẻ em.

- Ủu đãi đối với phụ nữ mới dừng lại ở việc hỗ trợ cho phụ nữ thuộc hộ nghèo là người dân tộc thiểu số khi sinh con đúng chính sách dân số.

- Hỗ trợ về dinh dưỡng mới chỉ dành cho người nghèo điều trị nội trú tại cơ sở khám chữa bệnh công lập.

Thêm nữa, các quyền nói trên chủ yếu mới tập trung vào quyền sống. Các quyền liên quan đến nhu cầu và điều kiện phát triển chưa được thể hiện trong nội dung chính sách. Đó là các quyền được phát triển gắn liền với việc tiếp cận, nghiên cứu, thụ hưởng các giá trị vật chất, tinh thần và những thành quả của khoa học - công nghệ, văn học, nghệ thuật, các giá trị văn hóa. Nghị quyết 80/NQ-CP có nhắc tới việc hỗ trợ người nghèo hưởng thụ văn hóa, thông tin thông qua việc "Tổ chức thực hiện tốt chương trình đưa văn hóa, thông tin về cơ sở; đa dạng hóa các hoạt động truyền thông, giúp người nghèo tiếp cận các chính sách giảm nghèo, phổ biến các mô hình giảm nghèo có hiệu quả, gương thoát nghèo". Tuy nhiên, đây mới là phương hướng chung, chưa có các quy định cụ thể để thực hiện. Hơn nữa, về bản chất quyền hưởng thụ văn hóa và quyền thông tin là tách biệt nhau, và tiếp cận đa chiều mới giải quyết quyền thông tin ở ngưỡng tối thiểu.

Là một trong những nhóm người dễ bị tổn thương trong xã hội, nhà nước cần chủ động trao cơ hội để người nghèo có thể thực hiện đủ các quyền trên các phương diện khác nhau.

Thư hai, sư nhất quán trong quan niệm của một số chính sách liên quan tới quyền con ngườ
05 thiếu hụt và 05 chính sách trong nhóm hỗ trợ tiếp cận dịch vụ xã hội cơ bản tương hiện nay có sự tương đồng rất lớn với nhiều nội dung chính sách khác. Điển hình như quan niệm về các dịch vụ xã hội trong quản lý đô thị hiện nay trong Chỉ thị số 24/CT-TTg ngày 02.8.2016 của Thủ tướng Chính phủ về việc tăng cường phát triển hệ thống dịch vụ xã hội đô thị đảm bảo an sinh xã hội. Theo đó, hệ thống dịch vụ xã hội tại khu đô thị được định danh cụ thể gồm các dịch vụ: 1/ Nhà ở xã hội cho người dân; 2/ Nước sạch, vệ sinh môi trường; 3/ Y tế; 4/ Giáo dục; 5/ Văn hóa, thể thao, giải trí, sinh hoạt cộng đồng.

Sự tương đồng này cho thấy bước đầu đã có một tư duy tổng thể trong việc xây dựng chính sách xã hội nói chung. Các quyền con người cơ bản đã được thể hiện rõ trong nội dung các chính sách. Tuy nhiên, theo phân loại dịch vụ công, 05 dịch vụ được tập trung phát triển cũng như 05 chiều nghèo được sử dụng để đo lường mới chỉ phù hợp với nhánh dịch vụ công cộng. Khía cạnh liên quan tới các quyền hành chính trong sinh hoạt cộng đồng chưa được chú trọng. Nói cách khác, chưa có chính sách làm tăng cơ hội thực hiện các quyền về hành chính của người nghèo trong sinh hoạt cộng đồng. Đương nhiên, pháp luật và chính sách không phân biệt đối xử về cơ hội thực hiện các quyền này giữa người nghèo và những người khác. Song, trên thực tế, do phải dành toàn bộ quỹ thời gian và sự nỗ lực cho các vấn đề liên quan tới sinh kế, người nghèo thường ít chú trọng tới việc thực hiện các quyền này.

Một biểu hiện nữa của sự nhất quán chính sách là việc phối hợp thực hiện song song 02 chương trình mục tiêu quốc gia là Chương trình mục tiêu quốc gia giảm nghèo bền vững và Chương trình mục tiêu quốc gia xây dựng nông thôn mới. Mục tiêu và phương thức thực hiện 02 chương trình có nhiều điểm giao thoa với nhau. Kết quả việc thực hiện nhiều nội dung trong chương trình này là tiền đề để thực hiện chương trình kia. Đây là một điều kiện thuận lợi để các mục tiêu bình đẳng và phát triển sớm có cơ hội trở thành hiện thực, "không để ai bị bỏ lại phía sau” [8] trong quá trình phát triển. 
Thư ba, chính sách tập trung vào ngữong tối thiểu trong việc thực thi các quyền co bản đã xác định

Nếu coi nghèo là sự thiếu thụt, thì giảm nghèo là quá trình xây dựng và thực thi các chính sách nhằm bù đắp các thiếu hụt đó. Có thể phân nhóm các thiếu hụt mà người nghèo phải đối mặt trên 03 phương diện cơ bản: 1/ Thiếu hụt về thu nhập; 2/ Thiếu hụt về cơ hội tiếp cận các dịch vụ xã hội cơ bản; 3/Thiếu hụt về vị thế trong cộng đồng. Chính sách giảm nghèo cần phủ khắp được các thiếu hụt này.
Như đã đề cập, Chỉ thị số 01/CT-TTg về việc tăng cường chỉ đạo thực hiện Chương trình mục tiêu quốc gia Giảm nghèo bền vững giai đoạn 2016-2020 yêu cầu các cấp, ngành tập trung vào 03 nhóm chính sách chủ yếu là: $1 /$ Hỗ trợ phát triển sản xuất, nâng cao thu nhập cho hộ nghèo; 2/ Hỗ trợ hiệu quả cho người nghèo tiếp cận các dịch vụ xã hội cơ bản, ưu tiên cho các dịch vụ gắn với tiêu chí nghèo đa chiều như y tế, giáo dục, nhà ở, nước sạch và vệ sinh, thông tin; 3/ Phát triển hạ tầng các vùng khó khăn, vùng có tỷ lệ hộ nghèo cao.

Bảng 5. Thực tiễn Chính sách giảm nghèo so với quan niệm về thiết hụt của người nghèo

\begin{tabular}{|c|c|c|c|}
\hline $\begin{array}{l}\text { Thiếu hụt } \\
\text { của người nghèo }\end{array}$ & $\begin{array}{l}03 \text { trọng tâm chính sách giai } \\
\text { đoạn } 2016 \text { - } 2020\end{array}$ & Kỳ vọng & $\begin{array}{l}\text { Không xếp loại được các chính } \\
\text { sách đã có }\end{array}$ \\
\hline Thiếu hụt về thu nhập & $\begin{array}{l}\text { 1/ Hỗ trợ phát triển sản xuất, } \\
\text { nâng cao thu nhập cho hộ } \\
\text { nghèo }\end{array}$ & & $\begin{array}{l}\text { - Hỗ trợ tiền điện } \\
\text { - Trợ giúp pháp lý } \\
\text { - Uu tiên xây dựng chính quyền }\end{array}$ \\
\hline $\begin{array}{l}\text { Thiếu hụt về co hội tiếp } \\
\text { cận các dịch vụ xã hội } \\
\text { cơ bản }\end{array}$ & $\begin{array}{l}\text { 2/ Hỗ trợ hiệu quả cho người } \\
\text { nghèo tiếp cận các dịch vụ xã } \\
\text { hội cơ bản, ưu tiên cho các } \\
\text { dịch vụ gắn với tiêu chí } \\
\text { nghèo đa chiều như y tế, giáo } \\
\text { dục, nhà ở, nước sạch và vệ } \\
\text { sinh, thông tin } \\
\text { 3/ Phát triển hạ tầng các vùng } \\
\text { khó khăn, vùng có tỷ lệ hộ } \\
\text { nghèo cao }\end{array}$ & & $\begin{array}{l}\text { cơ sở } \\
\text { - Thu hút nhân lực các lĩnh vực } \\
\text { trọng yếu }\end{array}$ \\
\hline $\begin{array}{l}\text { Thiếu hụt về vị thế } \\
\text { trong cộng đồng }\end{array}$ & & $\begin{array}{l}\text { Hỗ trợ nâng cao } \\
\text { năng lực cho người } \\
\text { nghèo }\end{array}$ & \\
\hline
\end{tabular}

Như vậy, các xác định trọng tâm chính sách trong giai đoạn này nhất quán với phương pháp tiếp cận đa chiều. Đây là tiền đề thuận lợi cho quá trình điều hành, giám sát thực hiện và tổng kết báo cáo của các cơ quan có thẩm quyền. Ngày 11/4/2017, Thủ tướng Chính phủ ban hành Quyết định 442/QĐ-TTg Chương trình công tác năm 2017 của Ban chỉ đạo Trung ương các chương trình mục tiêu quốc gia giai đoạn 2016 - 2020 trong đó nêu rõ lộ trình và phân công cụ thể các cá nhân trong bản chỉ đạo phụ trách từng phần việc để hiện thực hóa việc rà soát, sửa đổi, bổ sung chính sách giảm nghèo, tích hợp chính sách thuộc các lĩnh vực bảo đảm đồng bộ, hiệu quả, dễ theo dõi, dễ thực hiện. Việc làm này tiếp tục cho thấy sự nhất quán trong quan điểm chỉ đạo của nhà nước về chính sách giảm nghèo bền vững, đồng thời khẳng định quyết tâm thực hiện có hiệu quả các mục tiêu quan trọng để thúc đẩy xã hội phát triển của chính phủ.

Việc xác định nội dung các trọng tâm và cách sắp thứ tự của các trọng tâm cho thấy việc đạt tới ngưỡng tối thiểu của quyền con người về y tế, giáo dục, nhà ở, môi trường và thông tin được ưu tiên hơn hết. Các quyền khác, mặc dù đã có chính sách, nhưng được hiểu là không nằm trong ưu tiên của giai đoạn này. Đây là 
một lựa chọn hợp lý so với tiếp cận theo nhu cầu của con người, nhất là đối với người nghèo, song nếu nhìn nhận trên bình diện của HRBA, những lựa chọn này chưa đầy đủ và cần được mở rộng. Đặc biệt cần thiết lập các chính sách hướng tới tăng cường năng lực xã hội cho người nghèo, nâng cao vị thế của người nghèo trong cộng đồng, phòng và chống những tác động tiêu cực về quan hệ xã hội do phân cách giàu nghèo gây ra, giúp người nghèo vươn lên thoát nghèo và khẳng định giá trị của bản thân.

2.3.2. Về việc làm rõ vai trò của nhà nước trong việc cung cấp điều kiện thưc hiện quyền con người của người nghèo

Nghèo là tình trạng thiếu hụt và chính sách giảm nghèo là những hỗ trợ của nhà nước nhằm giúp bù đắp các thiếu hụt đó cho người nghèo. Dưới góc độ quyền con người, thực tế nghèo và hệ quả của nghèo gây ra tình trạng người nghèo không thể thực hiện hoặc thực hiện không đầy đủ các quyền con người của mình. Cũng theo tiếp cận này, như đã phân tích, khi chủ thể của quyền (Rights-Holders) không được đáp ứng quyền của mình, thì chủ thể có nghĩa vụ (DutyBearers) có trách nhiệm phải cung cấp mọi phương tiện để chủ thể của quyền có thể đạt được các quyền của mình. Nội dung chính sách giảm nghèo ở Việt Nam hiện nay hoàn toàn phù hợp với yêu cầu này.

Nhà nước giữ vai trò là chủ thể hỗ trợ toàn bộ các thiếu hụt của người nghèo. Toàn bộ các hợp phần của chính sách giảm nghèo đang tập trung vào việc phân công các cơ quan thuộc bộ máy hành chính nhà nước trong việc cung cấp các điều kiện để người nghèo thực hiện các quyền con người đang bị hạn chế bởi trạng thái nghèo. Các cơ quan hành chính nhà nước từ trung ương tới địa phương thực hiện mọi hỗ trợ, từ tín dụng, lao động và việc làm, đến các dịch vụ xã hội cơ bản, các ưu tiên phát triển kinh tế xã hội khác...

Nhà nước có khuyến khích các chủ thể ngoài nhà nước tham gia vào việc thực hiện các tác động hỗ trợ. Tất cả các nội dung chính sách đều trao cho địa phương thẩm quyền kêu gọi và sử dụng các nguồn hỗ trợ hợp pháp từ khu vực ngoài nhà nước. Tuy nhiên, kể cả trong chủ trương và trong thực tiễn thực hiện chủ trương, vai trò của nhà nước vẫn là vai trò chủ đạo. Điển hình như tương quan vốn đầu tư thực hiện Chương trình mục tiêu quốc gia giảm nghèo bền vững giai đoạn 2016 - 2020 theo quyết định 1722/QĐ-TTg ngày 02.9.2016, tổng kinh phí thực hiện được xác định tại Khoản 1 Điều 1 gồm Tổng kinh phí thực hiện Chương trình: 48.397 tỷ đồng, dự kiến huy động từ các nguồn: Ngân sách trung ương: 41.449 tỷ đồng (vốn đầu tư: 29.698 tỷ đồng; vốn sự nghiệp: 11.751 tỷ đồng); Ngân sách địa phương: 4.848 tỷ đồng (vốn đầu tư: 3.452 tỷ đồng, vốn sự nghiệp: 1.396 tỷ đồng); Vốn huy động hợp pháp khác: 2.100 tỷ đồng.

Việc nhà nước xác định vai trò chủ đạo của mình trong việc thực hiện giảm nghèo là một biểu hiện rất quan trọng của quan niệm về chức năng xã hội của nhà nước. Mọi nhà nước đều có hai chức năng cơ bản là chức năng giai cấp/chuyên chính/quản lý/thống trị và chức năng xã hội/phục vụ. Mặc dù chức năng giai cấp là chức năng quan trọng nhất, song nhiều học thuyết có thế giới quan khác nhau đều công nhận chức năng xã hội và việc thực hiện tốt chức năng xã hội lại là cơ sở đảm bảo cho sự tồn tại của địa vị giai cấp trong bộ máy nhà nước, từ đó là tiền đề cho việc thực hiện chức năng giai cấp. Trong xu thế hiện nay, chức năng xã hội đang ngày càng được đề cao và chứng tỏ vai trò quan trọng của mình đối với sự tồn tại và phát triển của quốc gia.

Chức năng xã hội của nhà nước là các phương diện hoạt động nhằm thực hiện các trách nhiệm xã hội liên quan tới lợi ích của bộ phận/toàn bộ cư dân. Từ thời cổ đại, Aristoteles đã coi việc thực hiện chức năng xã hội là một tiêu chuẩn quan trọng để đánh giá nhà nước. Đối với Việt Nam, việc thực hiện tốt chức năng xã hội còn liên quan trực tiếp tới các vấn đề về bản chất chế độ chính trị, thể hiện được sự tiếp nối đối với truyền thống văn hóa dân tộc, góp phần chủ đạo tạo nên sự bình ổn của xã hội, tạo ra tiền đề cho việc thực hiện các chức năng khác của nhà nước. Trong xu thế hội nhập và mở rộng hợp tác, việc đẩy mạnh thực hiện tốt 
chức năng xã hội là một tất yếu đã được nắm bắt thông qua các chủ trương lớn của chính phủ, mà điển hình là quyết tâm xây dựng một chính phủ kiến tạo với các trọng tâm phục vụ, phát triển, đẩy mạnh cải cách thể chế, tạo thuận lợi cho người dân, doanh nghiệp năng động, đổi mới, sáng tạo trong hơn 01 năm qua.

Xây dựng và thực thi chính sách giảm nghèo chỉ là một nội dung nhỏ trong việc thực hiện chức năng xã hội của nhà nước. Như các nội dung khác, với tư các là một biểu hiện của việc thực hiện chức năng xã hội, nhà nước sẽ thực hiện các nhiệm vụ chủ đạo gồm xây dựng hệ thống chính sách và tổ chức thực thi chính sách. Trong cả 02 nhiệm vụ này, nhà nước đều đã có sự phân công thực hiện giữa các cơ quan trong bộ máy nhà nước:

- Về xây dựng chính sách:

+ Chính phủ đưa ra các quy định chung về phương pháp tiếp cận đo lường nghèo và các tiêu chuẩn chủ yếu, đồng thời giao quyền cho các địa phương xác định mức độ của các tiêu chuẩn sao cho phù hợp (khuyến khích cao hơn chuẩn nghèo chung).

+ Chính phủ quy định việc sử dụng ngân sách nhà nước trong thực thi chính sách, bao gồm cả ngân sách trung ương, ngân sách địa phương (gồm cả vốn đầu tư phát triển và vốn sự nghiệp) và các nguồn vốn huy động hợp pháp khác.

+ Chính phủ giao cho các bộ, ngành liên quan trách nhiệm làm đầu mối chủ trì, hướng dẫn và phối hợp thực hiện các phần nội dung phù hợp với chuyên môn

- Về thực thi chính sách:

+ Chính phủ giao cho các địa phương quyền và trách nhiệm tổ chức triển khai chính sách. Địa phương có quyền chủ động huy động vốn, đồng thời chịu trách nhiệm về việc sử dụng các nguồn vốn đúng mục tiêu, đảm bảo hiệu quả, tiết kiệm và tránh thất thoát.

+ Địa phương có trách nhiệm báo cáo định kỳ hoặc đột xuất về tình hình triển khai thực hiện.
Như vậy, tất cả các hỗ trợ đối với người nghèo hiện nay đều chủ yếu do hệ thống các cơ quan hành chính nhà nước từ trung ương đến địa phương thực hiện. Các cơ quan này đều được phân quyền và giao trách nhiệm cụ thể trong từng nhiệm vụ chính sách. Vai trò của nhà nước trong việc cung cấp điều kiện thực hiện quyền con người của người nghèo được xác định rõ ràng. Kết quả của việc thực hiện giảm nghèo tại các địa phương được coi là một thông số quan trọng trong đánh giá năng lực điều hành của bộ máy hành chính nhà nước tại địa phương, và năng lực cạnh tranh của địa phương trong việc thu hút vốn đầu tư.

2.3.3. Về việc nâng cao năng lực của nguời nghèo và tính chủ động của các co quan nhà nước

Thư nhất, về việc nâng cao năng lục của người nghèo.

Chương trình mục tiêu quốc gia giảm nghèo bền vững giai đoạn 2016 -2020 là chương trình được hợp nhất từ các Chương trình mục tiêu quốc gia giảm nghèo, chương trình $30 \mathrm{a}$, Chương trình 135, Chương trình đưa lao động ở huyện đi làm việc có thời hạn ở nước ngoài và Chương trình đưa thông tin về cơ sở miền núi, vùng sâu, vùng xa, biên giới hải đảo. Ngoài những thay đổi do việc sử dụng tiếp cận đa chiều tạo ra, một điểm mới nổi bật khác trong phương thức thực hiện chính sách là việc chuyển từ cho không sang hỗ trợ có điều kiện. Mục đích của việc làm này là nâng cao ý thức, trách nhiệm của người nghèo trong phát triển sản xuất kinh doanh, hạn chế tối đa tâm lý ỷ lại, sợ thoát nghèo để chờ cấp phát. Nói cách khác, phương pháp hỗ trợ được sử dụng ở đây là cho người nghèo "cần câu cơm chứ không cho con cá".

Điển hình như trong nhóm chính sách hỗ trợ phát triển sản xuất, nâng cao thu nhập cho hộ nghèo, việc cấp phát lương thực chỉ dành cho hộ nghèo ở thôn, bản vùng giáp biên giới trong thời gian chưa tự túc được lương thực; tiền mua giống, phân bón cho việc chuyển đổi cây trồng, vật nuôi có giá trị kinh tế cao; ưu tiên hỗ trợ trồng lúa lai, ngô lai; mua giống, phân 
bón cho việc chuyển đổi cây trồng, vật nuôi có giá trị kinh tế cao; ưu tiên hỗ trợ trồng lúa lai, ngô lai là nội dung duy nhất được quy định cấp phát trực tiếp 01 lần.

Song song với việc lấy người nghèo làm trung tâm của hoạt động hỗ trợ, chương trình còn mở rộng thêm sang các đối tượng hộ cận nghèo, hộ mới thoát nghèo. Đây là một bước đi quan trọng của tư duy bền vững, bởi nâng cao năng lực cho các đối tượng có nguy cơ rơi vào trạng thái nghèo sẽ làm giảm đi đáng kể khả năng trở thành hộ nghèo của họ; làm giảm đi tình trạng lợi dụng chính sách để xác nhận nghèo luân phiên cho những hộ không nghèo; và làm giảm dần tâm lý không muốn thoát nghèo của nhiều hộ dân do lo sợ đột ngột bị cắt giảm các hỗ trợ từ nhà nước và cộng đồng mà trạng thái thoát nghèo gây ra.

Ngoài nội dung chính sách, trong rất nhiều phát biểu chỉ đạo, người đứng đầu chính phủ cũng nhiều lần khẳng định mong muốn đẩy mạnh hoạt động tôn vinh để người dân chủ động vươn lên thoát nghèo.

Thư hai, về tính chủ động của co quan hành chính nhà nước ở địa phương

Như đã phân tích, tính chủ động của co quan hành chính nhà nước ở địa phương được thể hiện ở việc thực hiện các nhiệm vụ được phân cấp, phần quyền trong các văn bản chính sách. Hiện nay, các nội dung chủ yếu được giao cho địa phương chủ động thực hiện là: 1/ Xác định chuẩn nghèo phù hợp với thực tế địa phương trên cơ sở các tiêu chí chung; 2/Huy động và sử dụng các nguồn vốn hợp pháp ngoài ngân sách để thực hiện chương trình. Trên thực tế, vì nhiều lý do khác nhau, sự chủ động này đang diễn ra chưa đồng đều ở các địa phương. Để đạt được mục tiêu chính sách, ngoài sự đúng đắn về nội dung, sự nỗ lực "kéo thuyền" của chính phủ, cần có sự tham gia chủ động và có hiệu quả vào việc "đẩy thuyền" của các địa phương. Để nâng cao tính chủ động, cần phối hợp thực hiện các chủ trương nâng cao năng lực công chức, cải cách bộ máy hành chính, tăng cương chế độ đãi ngộ... Thực tế này một lần nữa cho thấy các vấn đề xã hội không tồn tại biệt lập với nhau, và để thực thi có hiệu quả các trách nhiệm xã hội của mình, nhà nước buộc phải làm mạnh bản thân mình trước hết.

Bên cạnh trách nhiệm thực thi các nội dung được quy định trong văn bản chính sách, tính chủ động của cơ quan hành chính nhà nước còn được thể hiện thông qua sự kỳ vọng đối với trách nhiệm của cá nhân người đứng đầu và các chế tài nếu có sai phạm xảy ra. Việc quy trách nhiệm cá nhân người đứng đầu đang được đặc biệt quan tâm. Đây là nội dung thường xuyên được những người đứng đầu chính phủ nhắc tới trong các chỉ đạo thực hiện chính sách [9], và được đề nghị bổ sung làm rõ trong quá trình dự thảo nhiều văn bản quy phạm pháp luật [10]. Đối với chính sách giảm nghèo, cần nghiên cứu để xây dựng quy định cư thể về trách nhiệm cá nhân của người đứng đầu trong thực thi chính sách. Hoàn toàn có thể tham khảo các quy định tương tự đã có trong Chương trình mục tiêu quốc gia xây dựng nông thôn mới tại Chỉ thị 36/CT-TTg ngày 30/12/2016 về việc đẩy mạnh thực hiện hiệu quả, bền vững chương trình mục tiêu quốc gia xây dựng nông thôn mới giai đoạn 2016 - 2020.

Sự thống nhất trong nhận thức và chủ động sáng tạo trong hành động của các cấp hành chính là điều kiện quan trọng để nhà nước thực hiện thành công vai trò của người có nghĩa vu thực hiện quyền đối với các nhóm xã hội yếu thế nói chung, và đối với người nghèo nói riêng.

\subsection{Quan tâm đồng đều tới muc tiêu chính sách và phuoong pháp thực hiện chính sách}

Trong các văn bản thể hiện nội dung chính sách giảm nghèo, các chủ thể ban hành văn bản đều thể hiện đầy đủ các quy định về mục tiêu chính sách và phương pháp thực hiện chính sách. Nhiều nội dung quan trọng còn được hướng dẫn thực hiện thông qua các văn bản phái sinh theo quy định của luật ban hành văn bản quy phạm pháp luật. Các hạn chế hiện nay chủ yếu phát sinh trong quá trình thực thi chính sách.

Nhóm chính sách hỗ trợ lao động và việc làm là nhóm chính sách có nội dung quan quan tâm đồng đều tới mục tiêu chính sách và 
phương pháp thực hiện chính sách. Cả mục tiêu và phương pháp đều có mối liên hệ trực tiếp và gián tiếp đối với các quyền cơ bản của con người. Về mục tiêu, chính sách gắn với quyền làm việc, lựa chọn nghề nghiệp, việc làm và nơi làm việc của con người. Về phương thức, chính sách đặt vấn đề giao đất sản xuất cho hộ nghèo. Nơi không còn đất sản xuất thì hỗ trợ chuyển đổi nghề, xuất khẩu lao động, giao khoán bảo vệ rừng và trồng rừng. Bên cạnh đó là hàng loạt các hỗ trợ gián tiếp để tăng cường cơ hội như: hỗ trợ dịch vụ bảo vệ thực vật, thú $\mathrm{y}$, vệ sinh an toàn thực phẩm; hỗ trợ địa phương tiền xúc tiến thương mại, quảng bá, giới thiệu sản phẩm, nhất là nông, lâm, thủy đặc sản của địa phương; thông tin thị trường cho nông dân...

\section{3. Đề xuất định hướng xây dựng chính sách giảm nghèo}

Nhìn chung, nội dung chính sách giảm nghèo ở Việt Nam hiện nay đã có rất nhiều điểm tương thích với các yêu cầu của HRBA. Để hoàn thiện nội dung chính sách theo hướng tiệm cận hơn tới HRBA, cần lưu ý tới các vấn đề sau:

\section{Thách thíc}

Có nhiều thách thức đối với việc áp dụng HRBA trong xây dựng chính sách xã hội nói chung và chính sách giảm nghèo nói riêng. Dưới đây là các thách thức cơ bản từ phía nhà nước và từ phía người nghèo.

\section{Đối với nhà nước}

HRBA là một vấn đề còn tương đối mới mẻ, đặc biệt là với các cơ quan hành chính nhà nước ở địa phương, với đội ngũ cán bộ công chức. Nhận thức và kỹ năng phân tích, vận dụng cách tiếp cận này trong xây dựng và thực hành chính sách còn nhiều hạn chế. Cùng đó, tâm lý ngại thay đổi, dè chừng khi tiếp cận cái mới sẽ làm tiến độ triển khai bị ảnh hưởng đáng kể.

Nội dung của cách tiếp cận này có tác động to lớn và mạnh mẽ tới toàn bộ quá trình hoạch định và thực thi chính sách theo hướng làm rõ trách nhiệm của nhà nước và gia tăng trách nhiệm cá nhân người đứng đầu. Điều này khiến các cá nhân/nhóm đang hưởng lợi từ việc thiếu minh bạch trong bộ máy nhà nước gây ra cản trở đối với việc triển khai.

\section{Đối với người nghèo}

Tiếp cận dựa trên nhu cầu là một thành tựu lớn trong giai đoạn trước, và đang tiếp tục có ảnh hưởng sâu sắc tới giai đoạn hiện nay. Cơ chế "xin - cho", một biến thể không mong muốn của tiếp cận này đã tạo nên tâm lý ỷ lại, thiếu chủ động của đối tượng điều chỉnh của nhiều chính sách, trong đó có chính sách giảm nghèo.

Hiệu lực và hiệu quả của nhiều chính sách lớn bị suy giảm khi về tới các cấp cơ sở do năng lực và đạo đức công vụ còn hạn chế của một bộ phận đáng kể trong đội ngũ cán bộ công chức. Tham nhũng, lạm quyền, thiếu trách nhiệm gây hậu quả nghiêm trọng đang dần làm mất niềm tin của người dân vào người thực thi chính sách.

\section{Giải pháp}

Về nội dung chính sách

- Tăng cường việc thừa nhận tính tất yếu của quyền con người trong hệ thống pháp luật nói chung.

- Rà soát nhằm phát hiện và điều chỉnh các nội dung chính sách không phù hợp hoặc mâu thuẫn với tiếp cận mới.

- Đối với các quyền đã được đề cập một phần: tiếp tục nghiên cứu và mở rộng phạm vi các hỗ trợ điều kiện thực hiện quyền con người của người nghèo.

- Với các quyền chưa được nghiên cứu và vận dụng: rà soát và xây dựng chính sách hỗ trợ thực hiện các quyền còn chưa được đề cập tới.

- Thường xuyên đánh giá tác động của chính sách và việc thực thi chính sách nhằm điều chỉnh các phương pháp thực thi sao cho phù hợp với từng đối tượng và trong từng thời điểm.

\section{Về đội ngũ thục thi chính sách}

- Khảo sát, đánh giá tình hình nhận thức và thực hiện HRBA trong đội ngũ tham gia xây dựng và thực thi chính sách. 
- Tập huấn, bồi dưỡng nâng cao nhận thức về quyền con người và sử dụng $\mathrm{HRBA}$ trong xây dựng và thực thi chính sách giảm nghèo.

- Thiết lập hệ thống kiểm tra định kỳ và đột xuất nhằm kiểm soát được hiệu quả thực hiện nhiệm vụ, đồng thời có những điều chỉnh cần thiết.

- Thể chế hóa rõ ràng và chặt chẽ trách nhiệm cá nhân người đứng đầu trong xây dựng và thực thi chính sách

\section{Đối với cộng đồng xã hộ}

- Đẩy mạnh truyền thông về HRBA, về các chính sách HRBA để bản thân người nghèo nhận thức được quyền và các giá trị hỗ trợ trên cơ sở quyền, đồng thời tạo nên sự đồng thuận trong cộng đồng xã hội

- Tiếp tục khuyến khích các chủ thể ngoài nhà nước tham gia vào việc thực thi chính sách

Mọi giải pháp để không thể thực hiện và có hiệu quả ngay trong một sớm một chiều. Nhưng, sự tương thích lớn giữa nội dung chính sách giảm nghèo và $\mathrm{HRBA}$, cũng như những giá trị mà HRBA được kỳ vọng mang lại cho cộng đồng đang cho thấy tiềm năng của việc coi HRBA là một hướng tiếp cận phù hợp xu thế quốc tế và đảm bảo tính xã hội của nhà nước cần được nhân rộng.

\section{Kết luận}

Quyền con người là một giá trị chung được nhân loại thừa nhận, mang tính tất yếu, được công nhận bởi nhiều văn bản pháp lý của các quốc gia và của các tổ chức quốc tế. Là thành viên của Liên hợp quốc, Việt Nam đã gia nhập hầu hết các Công ước quốc tế quan trọng nhât về quyền con người và đang trong quá trình nội địa hóa các quy định về quyền con người vào hệ thống chính sách, pháp luật quốc gia.

Qua phân tích, có thể thấy, nội dung chính sách giảm nghèo ở Việt Nam hiện nay hoàn toàn tương thích với tiếp cận HRBA. Tiếp tục áp dụng HRBA trong thời gian tới không chỉ là định hướng tất yếu của quá trình phát triển, mà còn mang giá trị xã hội vô cùng to lớn. Với cách hiểu giảm nghèo là tạo ra các cơ hội và điều kiện để người nghèo thực hiện đầy đủ các quyền con người của mình, việc xây dựng và thực thi thành công chính sách giảm nghèo theo tiếp cận này là minh chứng quan trọng khẳng định trách nhiệm của nhà nước trong việc thúc đẩy quyền con người, đồng thời thể hiện sự tôn trọng đối với quyền con người trong nguyên tắc xây dựng chính sách của nhà nước. Đây là hướng đi cần được tôn trọng./.

\section{Tài liệu tham khảo}

[1] Văn phòng Điều phối viên Thường trú Liên Hợp Quốc: Bộ tài liệu Phương pháp tiếp cận dựa trên $c o$ sở quyền con người dành cho cán bộ Liên Hợp Quốc tại Việt Nam: http://www.un.org.vn/vi/component/docman/doc_ details/115-a-human-rights-based-approachtoolkit.html?Itemid=266

[2] Vũ Công Giao, Ngô Minh Hương (Đồng chủ biên): Tiếp cận dựa trên quyền con người - Lý luận và thực tiễn, NXB Đại học Quốc Gia Hà Nội, 2016.

[3] Báo An ninh Thủ đô điện tử: http://anninhthudo.vn/chinh-tri-xa-hoi/tiep-candua-tren-quyen-con-nguoi/358322.antd, truy cập tháng 7/2017

[4] Báo điện tử của Đài Tiếng nói Việt Nam: http://vov.vn/chinh-tri/quoc-hoi-co-vai-tro-quantrong-doi-voi-su-phat-trien-quyen-con-nguoi370196.vov, truy cập tháng 7/2017

[5] Báo Công an Thành phố Hồ Chí Minh: http://congan.com.vn/tu-thien/be-chua-nuocnghia-tinh-cho-nguoi-ngheo-ben-tre_36037.html, truy cập tháng $7 / 2017$

[6] Báo điện tử VTV: http://vtv.vn/trong-nuoc/ho-tro1500-bon-chua-nuoc-cho-nguoi-ngheo-o-dbscl20170313090410175.html, truy cập tháng 7/2017

[7] Báo Cà Mau: http://baocamau.com.vn/van-hoaxa-hoi/thiet-thuc-ho-tro-ho-ngheo-xay-nha-vesinh-46156.html, truy cập tháng 7/2017

[8] Báo Lao động: http://laodong.com.vn/thoi-su-xahoi/ty-le-ho-ngheo-giam-chi-con-425-601543.bld, truy cập tháng 7/2017

[9] Tạp chí cộng sảng điện tử: http://www.tapchicongsan.org.vn/Home/Thoi_su/ 2017/45713/Kiem-diem-trach-nhiem-ca-nhan-tapthe-cham-giao-von-va.aspx, truy cập tháng 7/2017

[10] Báo điện tử Đảng Cộng sản Việt Nam: http://dangcongsan.vn/thoi-su/quy-ro-trachnhiem-co-quan-ca-nhan-trong-quan-ly-su-dungno-cong-442055.html, truy cập tháng 7/2017. 


\title{
Approach Based on Human Rights in Poverty Reduction Policies of Vietnam
}

\author{
Ta Thi Bich Ngoc \\ VNU University of Social Sciences and Humanities, 336 Nguyen Trai, Hanoi, Vietnam
}

\begin{abstract}
One of the eight Millennium Development Goals is to eliminate extreme poverty and hunger. In Vietnam, for decades, poverty reduction policy has been implemented on the basis of the needs of the poor and the resources of the state. Using the human rights-based approach, the paper reviews the main content of poverty reduction policy in Vietnam at present and suggests policy orientations in the coming time.
\end{abstract}

Keywords: Poverty Reduction, Poverty reduction policy, Sustainable poverty reduction policy, Human rights based approach, Human rights. 